\title{
BUDIDAYA SAYURAN ORGANIK DI LAHAN SEMPIT SAAT PANDEMI COVID-19 SEBAGAI PENINGKATAN KETAHANAN PANGAN
}

\author{
Khoiriyah Trianti1 ${ }^{*}$, Denny Febriyanto², Zainal Abidin² \\ ${ }^{1}$ Fakultas Ilmu Administrasi, Universitas Islam Malang \\ ${ }^{2}$ Fakultas Pertanian, Universitas Islam Malang \\ *Korespondensi email: khoiriyat@unisma.ac.id
}

\begin{abstract}
ABSTRAK
Salah satu upaya yang dapat dilakukan untuk meningkatkan ketahanan pangan kepada masyarakat sekitar di saat pandemi covid adalah dengan menerapkan bercocok tanam sayuran organik dilahan sempit. Selain dapat memanfaatkan lahan yang sempit untuk tanaman organik, juga dapat mengurangi limbah rumah tangga, memberikan pemahaman tentang manfaat penerapan pertanian secara organik, memberikan alternative tentang bahan-bahan insitu yang dapat digunakan untuk penerapan sistem pertanian organik, dan untuk mendapatkan jalur kemitraan untuk pemasaran produk organik. Untuk teknik pengumpulan data menggunakan teknik deskriptif, serta pada analisis data penulis malakukan berbagai penyaringan atau klarifikasi dari sumber-sumber informasi yang terpercaya sesuai yang dibutuhkan. Hasil yang dicapai yaitu pemahaman bahwa perlunya kita beralih ke konsep pertanian organik yang memperhatikan aspek ekonomi, social, dan lingkungan sehingga produkyang dihasilkan sehat dan aman dikonsumsi. Hal itu bisa dimulai dari penggunaan limbah kotoran hewan yang ada disekitar lingkungan kita untuk dijadikan pupuk organik.
\end{abstract}

Kata Kunci: sayuran organik; limbah organik; lahan; pangan.

\section{PENDAHULUAN}

Petani menghadapi banyak permasalahan dalam perannya menghasilkan bahan pangan. Selain permasalahan yang muncul pada aspek budidaya, lahan (tanah) dan pengendalian HPT (Hama dan Penyakit Terpadu), permasalahan petani dan pertanian di Indonesia begitu kompleks baik yang kemudian tergolong secara makro maupun mikro (Lukmanto \& Nirwansjah, 2015).

Pertanian organik merupakan salah satu sistem bertani yang akan mampu menggiring petani atau masyarakat untuk lebih peduli pada lingkungan dan memperhatikan faktor lingkungan dalam setiap aktivitas usaha tani yang dijalankan. Salah satu komponen yang bisa ditekan oleh petani jika dia menerapkan pertanian organik diantaranya adalah biaya pemberantasan hama serta pemupukan. Selama ini biaya pemberantasan hama dengan bahan kimiawi serta pemupukan kimiawi merupakan komponen biaya yang menyedot rupiah sangat besar bagi petani. Apabila biaya produksi dapat dikurangi, tentu harga produk yang dihasilkan akan lebih kompetitif, sehingga petani akan memiliki daya kompetisi yang lebih baik dengan produk-produk sejenis lainnya (Charina, Kusumo, Sadeli, \& Deliana, 2018).

Ilham \& Sinaga (2007) dengan topik yang sama meneliti ketahanan pangan menggunakan pendekatan pangsa pengeluaran pangan sebagai indikator karena dapat 
diukur dengan angka, cukup sederhana untuk memperoleh dan menafsirkannya, objektif, dan responsif terhadap perubahan-perubahan akibat adanya perubahan kondisi perekonomian, kebijakan dan program pembangunan. Rachman, Ariani, \& Purwantini, (2008) mengukur derajat ketahanan pangan dengan indikator mengombinasikan AKE dan PPP yang dibagi dalam empat kuadran. Faktor lingkungan dalam hal ini lahan (Mulyo et al., 2010) juga dapat mempengaruhi status ketahanan pangan petani sebagai penghasil pangan sehingga selain menunjukkan status ketahanan pangan juga dapat menunjukkan status kemandirian pangan mereka (Hasan et al., 2020; Mulyo, Sugiyarto, \& Widada, 2016; Adekoya, 2009).

Pertanian organik merupakan jawaban atas revolusi hijau yang digalakkan pada tahun 1960-an yang menyebabkan berkurangnya kesuburan tanah dan kerusakan lingkungan akibat pemakaian pupuk dan pestisida kimia yang tidak terkendali. Sistem pertanian berbasis high input energi seperti pupuk kimia dan pestisida dapat merusak tanah yang akhirnya dapat menurunkan produktifitas tanah. Pertanian organik sebenarnya sudah sejak lama dikenal, sejak ilmu bercocok tanam dikenal manusia, semuanya dilakukan secara tradisional dan menggunakan bahan-bahan alamiah. Pertanian organik modern didefinisikan sebagai sistem budidaya pertanian yang mengandalkan bahan-bahan alami tanpa menggunakan bahan kimia sintetis. Pengelolaan pertanian organik didasarkan pada prinsip kesehatan, ekologi, keadilan, dan perlindungan. Prinsip kesehatan dalam pertanian organik adalah kegiatan pertanian harus memperhatikan kelestarian dan peningkatan kesehatan tanah, tanaman, hewan, bumi, dan manusia sebagai satu kesatuan karena semua komponen tersebut saling berhubungan dan tidak terpisahkan (Mayrowani, 2012).

Dalam pembudidayaan sayuran organik dilahan yang sempit saat pandemi covid ini, masih banyak warga yang kurang memahami cara budidaya tanaman secara organik tidak hanya sebatas meniadakan penggunaan bahan sintetis, tetapi juga menuntut agar lahan yang digunakan tidak tercemar serta mempunyai aksesibilitas yang baik dan berkesinambungan. Dengan meningkatnya pendidikan dan pendapatan masyarakat maka pola konsumsi akan bergeser pada produk yang aman dari bahaya penggunaan bahan kimia pada budidaya pertanian (Sholihah \& Nurhidayati, 2018). oleh sebab itu akan mendorong masyarakat untuk memilih produk pertanian organik untuk dikonsumsi. Keunggulan lainnya dari mengkonsumsi produk organik adalah meningkatkan kesehatan bagi yang mengkonsumsi juga produk yang dihasilkan akan memiliki kualitas yang lebih baik, diantaranya lebih tahan disimpan dan meningkatnya nilai gizi pada produk tersebut (Karamina, Supriyadi, Firman Yasin, Yusi Kamhar, \& Kusuma Astuti, 2020).

\section{METODE}

Metode pelaksanaan ini mahasiswa bekerja sama dengan warga desa setempat mengenai apa yang perlu dikembangkan, dengan adanya usulan dari kelompok 75 untuk melaksanakan program kerja pokok yang sudah direncanakan yaitu Budidaya tanaman secara organik. Metode pelaksanaan yang dilakukan meliputi (1) observasi lapang, (2) meminta izin kepada Kepala Desa untuk melaksanakan program kerja, (3) melaksanakan program kerja sesuai yang sudah direncakan, (4) melaksanakan wawancara dan perekaman video.

Kegiatan ini dilaksanakan di salah satu tempat yang terletak di lingkungan Desa Sumber Kerang, Kecamatan Gending Kabupaten Probolinggo Provinsi Jawa Timur, dengan ketinggian tempat $5 \mathrm{mdpl}$ dan temperatur rata-rata berkisar 27-30 derajat celcius. Berlangsung mulai 03 Agustus 2020 hingga 03 September 2020. Bahan-bahan yang digunakan dalam kegiatan ini adalah benih sayuran, media tanah, pupuk organik kotoran kambing, Em4, polibag ukuran $30 \times 20 \mathrm{~cm}$ dan $20 \times 18 \mathrm{~cm}$. Alat-alat yang digunakan dalam 
percobaan ini berupa ember plastik, gelas ukur, alat pengaduk, cangkul, gunting, dan alat tulis.

\section{HASIL DAN PEMBAHASAN}

Dengan berbagai pemaparan tentang kelebihan pertanian organik dan tingginya prospek pertanian organik didunia dari tahun ke tahun, diharapkan dapat mengubah pola pikir petani di Indonesia untuk beralih ke pertanian organik. Selain itu peran pemerintah juga sangat diperlukan. Sudah semestinya pemerintah melakukan sosialisasi secara besar besaran tentang pertanian organik dengan dukungan diberbagai aspek, mulai dari peluang pasar, keunggulan dan manfaat produk organik dan diberikannya jaminan kepada petani organik. Salah satu faktor yang menyebabkan petani enggan menerapkan pertanian organik adalah tidak adanya jaminan dari pemerintah bila mereka mengalami kerugian. Setidaknya pemerintah menyediakan atau menciptakan pasar organik di Indonesia agar petani tidak kesulitan untuk menjual dan memasarkan hasil pertanian organik mereka. Selain itu tidak adanya lahan khusus yang disediakan pemerintah untuk mensukseskan program pertanian organik, karena apabila wilayah pertanian organik yang tidak terisolasi dengan pertanian konvensional membuat pertanian organik lebih rawan terhadap hama.

Dalam hal ini Desa Sumber kerang rata-rata penduduknya sebagai petani bawang merah, sebagai petani bawang merah yang masih menerapkan penanamannya dilahan pertanian tentu masih banyak menggunakan bahan kimia dan pestisida yang berlebihan telah merusak keseimbangan unsur hara tanah dan keaneragaman hayati akibat siklus penanaman yang berlangsung terus-menerus untuk menjaga komoditinya.

Oleh karena itu perlunya beralih ke sistem pertanian berkelanjutan dengan memperhatikan aspek sosial dan lingkungan. Salah satu sistem pertanian yang merupakan implementasi dari sistem pertanian berkelanjutan adalah sistem pertanian organik. Budidaya tanaman secara organik tidak hanya sebatas meniadakan penggunaan bahan sintetis, tetapi juga menuntut agar lahan yang digunakan tidak tercemar serta mempunyai aksesibilitas yang baik dan berkesinambungan. Pemberian pupuk organik ke dalam tanah dapat mempengaruhi dan memperbaiki sifat-sifat tanah baik fisika, kimia maupun biologi tanah.

Dalam upaya untuk meningkatkan produktivitas dan kualitas sayuran organik dalam membantu perekonomian masyarakat Desa Sumber Kerang Kecamatan Gending, Kabupaten Probolinggo yaitu:

\section{Proses pembuatan pupuk organik dari kotoran hewan kambing dan pupuk} organik cair dari limbah sisa-sisa sayuran

Menurut Istiqomah \& Serdani (2018) mengemukakan bahwa tanaman membutuhkan unsur hara yang selalu tersedia selama siklus hidupnya untuk dapat tumbuh dan berproduksi dengan baik. Degradasi lahan yang disebabkan oleh penggunaan pupuk kimia yang berlebihan mempengaruhi kualitas produk sayuran yang dihasilkan. Budidaya tanaman yang ramah lingkungan perlu digiatkan untuk mengatasi masalah penurunan kualitas lahan. Penggunaan bahan organik dapat menjadi alternatif solusi untuk mengurangi ketergantungan terhadap penggunaan pupuk kimia dalam meningkatkan produktivitas tanaman sawi hijau. Penambahan bahan organik dalam tanah akan dapat memperbaiki struktur tanah dan meningkatkan stabilitas agregat tanah yang nantinya dapat memelihara aerasi tanah dengan baik dan dapat menunjang peningkatan efisiensi penggunaan pupuk. Salah satu jenis pupuk organik adalah pupuk kandang.

Pemberian kotoran kambing dapat meningkatkan kualitas tanah. Hal ini disebabkan bentuk kotoran kambing berupa granul sehingga menjadikan tanah 
memiliki ruang pori yang meningkat. Kotoran kambing memiliki sejumlah mikroba seperti Bacillus sp, Lactobacillus sp, Saccharomyces, Aspergillus, serta Aktinomycetes. Aktivitas mikroba dengan sekresi lendir mampu meningkatkan butiran halus tanah menjadi granul sehingga kualitas meningkat (Rahayu, Simanjuntak, \& Suprihati, 2014).

Proses pembuatan pupuk organik:

a. Menyiapkan alat dan bahan

b. Mengambil langsung kotoran kambing yang masih berbentuk bulat

c. Membuat media untuk memfermentasi butiran bulat kotoran kambing menjadi butiran halus dengan mencampurkan EM4 pertanian dengan molase/gula dan air dengan perbandingan, 1:1:50 yaitu 40ml EM4:40ml molase/gula cair:10L air.

d. Kemudian menyemprotkan ke butiran bulat kotoran kambing dengan merata dalam keadaan lembab dan juga tidak terlalu basah.

e. Selanjutnya dimasukkan dalam karung gelangsi dan difermentasi selama 10 hari dalam keadaan tertutup dan lembab.

f. Melakukan pencampuran dengan media tanah untuk proses penanaman sayuran organik.

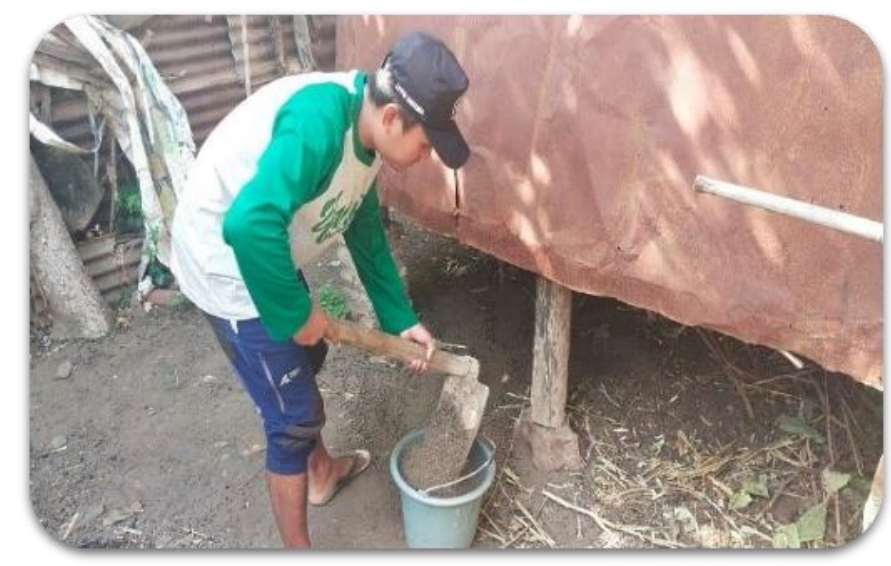

Gambar 1. Proses pembuatan Pupuk Organik

Pupuk organik cair (POC) yang digunakan pada pengabdian merupakan pupuk dari hasil limbah organik. Limbah tersebut berasal dari hasil pelapukan jaringan tanaman atau bahan tanaman seperti daun-daunan, kulit pisang dan rumput-rumputan termasuk sayuran yang berupa limbah organik yang mudah diperoleh dari lingkungan sekitar, didaur ulang dan dirombak dengan bantuan mikroorganisme perombak seperti bakteri lactobacillus dan saccharomyces yang terdapat pada EM4 menjadi unsur-unsur hara yang tersedia yang dapat diserap oleh tanaman.

Pupuk organik cair dapat berperan sebagai pengikat agregat primer menjadi agregat sekunder tanah. Keadaan ini memengaruhi penyimpanan unsur hara, penyediaan air, aerasi atau udara tanah, dan menstabilkan suhu tanah tanah. Bahan organik yang mengandung banyak karbon dan nitrogen, seperti jerami dan limbah sayuran lebih besar pengaruhnya pada perbaikan sifat-sifat fisik tanah sehingga memiliki fungsi yaitu penyediaan unsur hara seperti nitrogen, fosfor dan kalium yang sangat dibutuhkan oleh tanaman.

Proses Pembuatan Pupuk Organik Cair (POC):

a. Menyiapkan alat dan bahan

b. Memotong sisa-sisa limbah organik rumah tangga seperti sisa-sisa sayuran, kulit pisang 
c. Membuat media untuk fermentasi limbah organik dengan mencampurkan EM4 dengan molase/gula dan air dengan perbandingan $20 \mathrm{ml}$ EM4:100ml gula:15 L air

d. Semua bahan dimasukkan kedalam timba kemudian mencampurkannya jadi satu.

e. Kemudian disimpan selama 2 minggu ditempat yang lembab dan tertutup untuk proses fermentasi dan dilakukan pengecekan secara berkala dengan membuka tutupnya agar tidak menguap.

f. Setelah fermentasi selesai dilakukannya penyaringan dipisahkan dengan ampasnya, lalu dicampurkan dengan air dengan perbandingan $400 \mathrm{ml}$ pupuk organik cair dengan 15 Liter air dan dapat disiramkan ke tanaman setiap seminggu sekali.

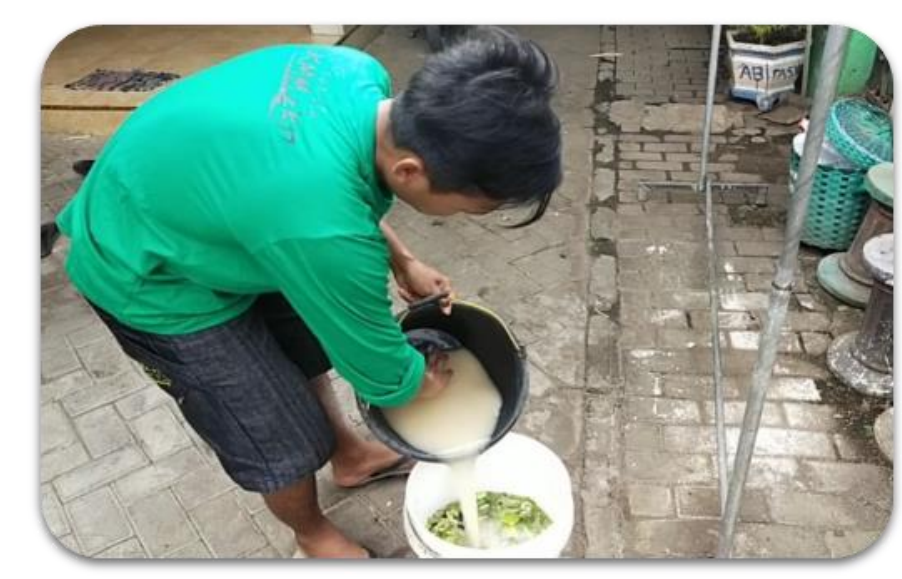

Gambar 2. Pembuatan Pupuk Cair limbah sayuran

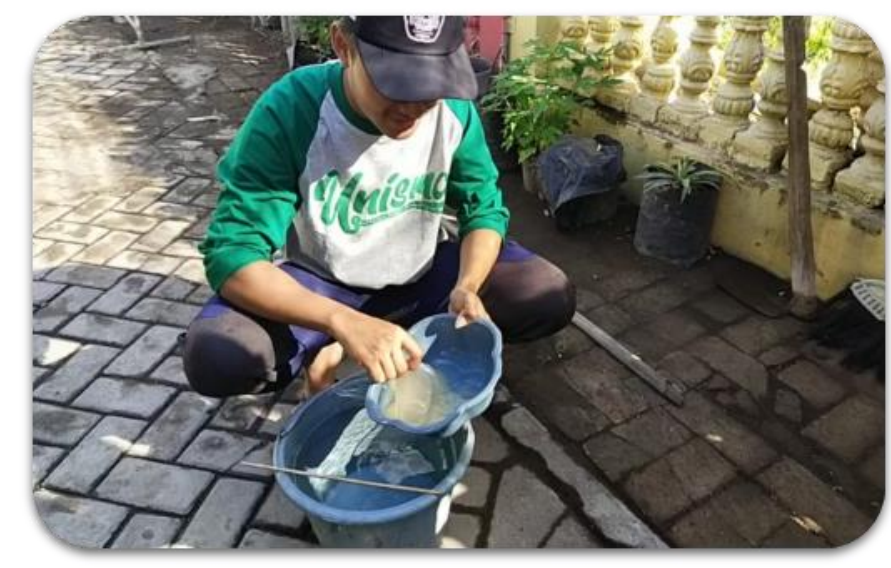

Gambar 3. Pemberian Pupuk Cair Organik ke tanaman sayuran setiap seminggu sekali

\section{Cara Menanam Sayuran Organik}

a. Persiapan Tempat yang Cukup Terpapar Sinar Matahari

Persiapan awal menanam sayuran organik adalah dengan mencari tempat yang memperoleh sinar matahari selama 8 jam penuh dalam sehari. Hal itu dikarenakan sebagian besar sayuran organik lebih suka tumbuh pada tempat yang terkena cahaya matahari. Sehingga proses fotosintesis tanaman tersebut menjadi sempurna, maka tingkat keberhasilan dalam berkebun pun menjadi terealisasikan.

b. Pemilihan Tanah yang Subur

Cara menanam sayuran organik berikutnya adalah pemilihan tanah yang subur. Bagi pemula sangat penting untuk memilih tanah dengan kualitas yang baik. Seimbangkan takaran pupuk kompos dengan kualitas tanah dan ketebalannya. Penyiraman air pada tanah juga usahakan pada kadar secukupnya saja. 
c. Pemilihan Tanaman yang Tepat Sesuai dengan Kondisi

Sebelum proses penanaman, lakukanlah riset untuk mengetahui jenis sayuran yang paling mungkin dapat tumbuh subur pada kondisi cuaca saat itu. Karena paparan sinar matahari dan rintikan curah hujan sangat mempengaruhi perjalanan proses tanaman selanjutnya.

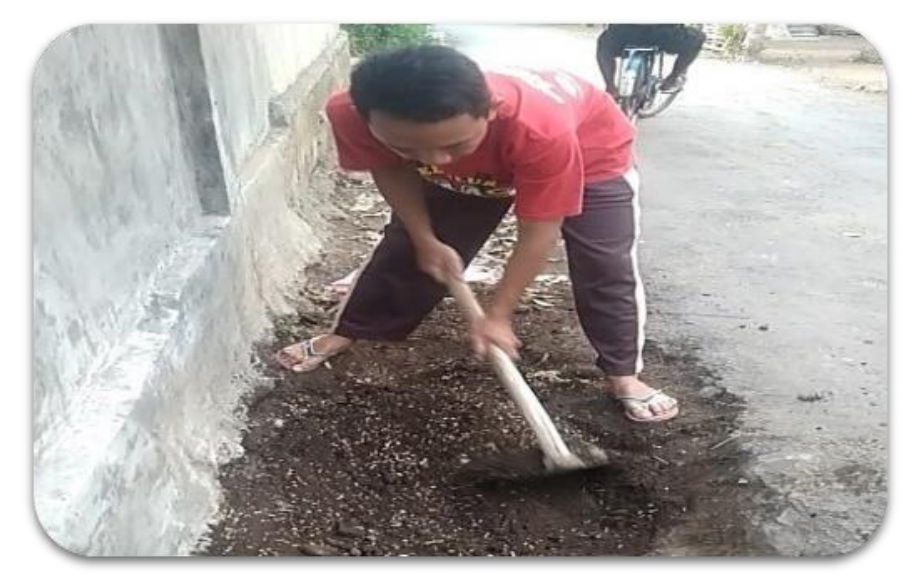

Gambar 4. Pembuatan media tanam sayuran organik

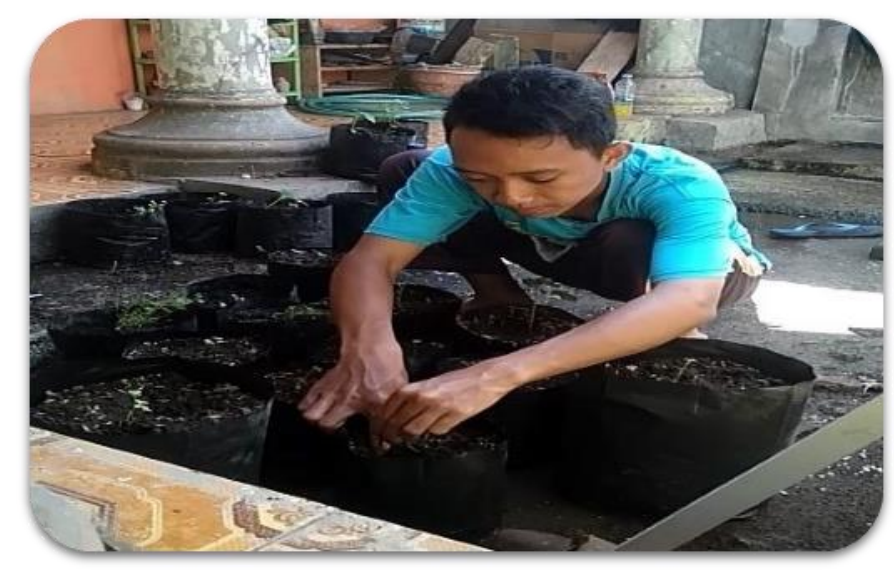

Gambar 5. Proses penanaman sayuran organik

\section{Perawatan sayuran organik}

Perawatan untuk budidaya sayuran organik sebenarnya tidaklah sulit, hanya saja Anda perlu memberi perhatian lebih untuk setiap hari memeriksanya. Pemeriksaan ini sangat penting guna menghindarkan sayuran organic dari kemungkinan terserang hama dan penyakit.

a. Lakukan penyiraman secara rutin setiap pagi dan sore dengan kadar yang pas sehingga tidak menyebabkan tanahnya becek.

b. Jangan lupa melakukan penyiangan terhadap area sekitar sayuran agar rumputrumput liar tidak tumbuh dan mengganggu pertumbuhan sayuran organic tersebut. Untuk menghambat pertumbuhan rumput liar, Selain itu Anda juga dapat menggunakan cara menghilangkan rumput dengan dicabut secara manual.

c. Pemberian pupuk pada sayuran organik memang sangat penting guna menambah kesuburan tanah demi menjaga agar pertumbuhan sayuran organic. Pupuk yang diberikan juga harus benar-benar terbebas dari bahan kimia. Salah satu pupuk yang dapat Anda buat sendiri di rumah adalah pupuk cair organik. Dengan pemberian pupuk cair organik seminggu sekali. 
d. Pengendalian hama, Sayuran organik memang sangat rentan diserang hama. Untuk dapat mengendalikan hama, Anda dapat melakukan pengendalian secara fisik, misalnya dengan membuang secara langsung dan menangkap.

e. Pemanenan, Untuk sayur organik ini dapat dipanen sesuai dengan jenis sayurnya, sebab setiap sayuran memiliki masa panen yang berbeda. Masa panen sayur organik juga tidak jauh berbeda dengan sayuran biasa, cara pemanenannya pun juga demikian.

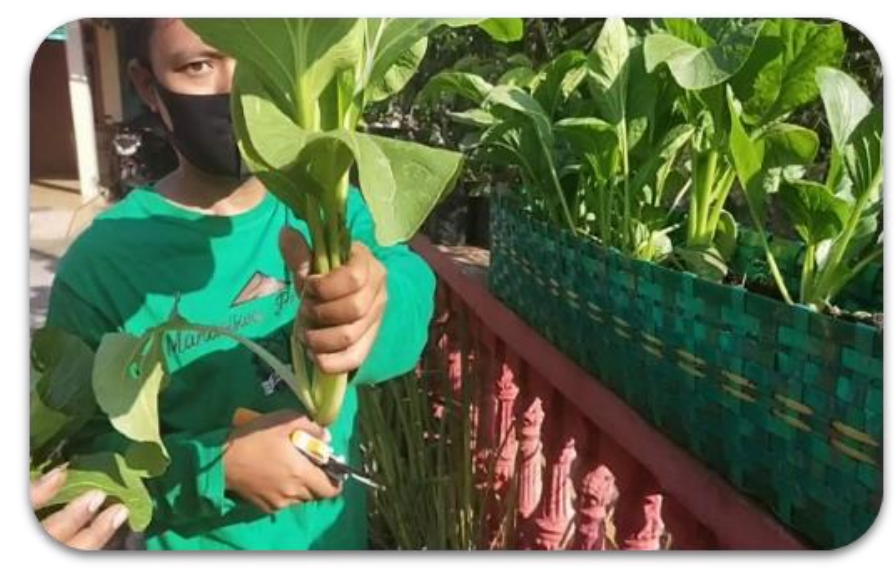

Gambar 6. Proses pemanenan sayuran organik

Tabel 1. Produksi Sayuran Organik di Indonesia pada Tahun 2011-2015 (Sumber: SPOI 2016)

\begin{tabular}{ccc}
\hline No. & Tahun & Produksi (Ton)/tahun \\
\hline 1 & 2011 & 145.446 \\
2 & 2012 & 224.300 \\
3 & 2013 & 307.471 \\
4 & 2014 & 395.139 \\
5 & 2015 & 487.490 \\
\hline
\end{tabular}

Terdapat peningkatan setiap tahunnya pada permintaan komoditas organik oleh masyarakat, sehingga hal ini dapat mendorong pertanian untuk beralih ke pertanian organik, dimana era sekarang masyarakat sudah banyak mengenal dan memahami tentang betapa banyak manfaat dari produk pertanian organik yang menjadikan ketertarikan masyarakat yang terus meningkat terhadap produk organik meski harus membayar lebih mahal, karena mereka sudah berpikir untuk mengkonsumsi produk yang sehat.

Adapun kelebihan dari pertanian organik yaitu:

a. Banyaknya aktivitas mikroorganisme di dalam tanah yang mampu meningkatkan kesuburan tanah.

b. Kandungan nutrisi dan gizi lebih tinggi

c. Meningkatkan cita rasa hasil pertanian

d. Meningkatkan masa penyimpanan

e. Nilai jual lebih tinggi

f. Biaya produksi yang dikeluarkan relatif lebih sedikit

Pertanian organik dapat dicapai dengan berbagai cara, maka hal itu dapat dimulai dari penggunaan pupuk organik yang ada disekitar lingkungan kita yang mudah dijumpai seperti pupuk kotoran kambing, dan sisa-sisa limbah organik rumah tangga dan masih banyak lagi yang dapat dijadikan sebagai pupuk organik. Cara menggunakannya dapat dikomposkan terlebih dahulu atau penerapan secara langsung, karena akan memberikan 
dampak yang baik bagi tanah maupun tanaman dan juga menjadi nilai tambah untuk kotoran yang tidak terpakai sehingga dapat dimanfaatkan. Kandungan pupuk organik memiliki banyak kandungan unsur hara makro maupun mikro yang lengkap sehingga dapat dimanfaatkan oleh tanaman, selain itu juga terdapat berbagai macam mikroorganisme yang mampu memperbaiki sifat fisik tanah dan sifat biologis tanah, sehingga keadaan tanah mampu menunjang pertumbuhan tanaman secara maksimal. Penggunaan pupuk organik secara besar besaran tidak akan memberikan dampak buruk bagi tanaman maupun lingkungan, bahkan dalam jumlah berlebihan sekalipun. Sehingga produk yang dihasilkan nantin memberikan nilai yang tinggi dari segi kualitas dan rasa.

\section{KESIMPULAN}

Berdasarkan hasil dari observasi lapangan yang telah kami lakukan di Dusun karnen wetan Desa sumber kerang, Kecamatan Gending, Kabupaten Probolinggo, Jawa Timur, dapat disimpulkan bahwa di kondisi pandemi covid ini mahasiswa dapat memberi solusi kepada masyarakat sekitar cara penanaman berbagai macam sayuran terutama bawang merah yang ditanam secara hidroponik dan juga organik untuk ditanam dilahan yang sempit dan tidak memerlukan modal yang tinggi sebagai media tempat tumbuhnya. Dan kami sebagai mahasiswa mempunyai peran penting untuk mengubah lingkungan ini menjadi lingkungan yang ramah dan sehat untuk mengembangkan dan menambah perekonomian masyarakat sekitar.

Pada Kuliah Kerja Nyata pembelajaran dan pengabdian masyarakat ini dapat diberikan saran sebagai berikut:

1. Sosialisasi pemahaman pada petani terhadap berbagai manfaat dari pertanian organic perlu dilakukan, selain itu adanya jaminan dari pemerintah sangat dibutuhkan untuk antisipasi jika petani mengalami resiko gagal panen.

2. Pembuatan pupuk organik cair dari bahan baku limbah sayuran mampu disosialisasikan dengan baik kepada masyarakat.

3. Tingkat pengetahuan dan pemahaman teknologi pengelahan limbah sayuran menjadi pupuk organik cair dapat diserap oleh masyarakat.

4. Pangsa pasar yang tepat sangat diperlukan dalam memasarkan produk pertanian organik agar banyak diminati masyarakat.

\section{UCAPAN TERIMA KASIH}

Terimakasih disampaikan kepada Bapak Abdullah Hidayat selaku Kepala desa Sumber kerang untuk mengsukseskan program kerja yang kami lakukan di desa Sumber kerrang dan seluruh pihak yang terlibat yang tidak dapat kami sebutkan satu persatu, serta pihak LPPM (Lembaga Penelitian dan Pengabdian Masyarakat) Universitas Islam Malang yang telah memberikan kesempatan untuk melaksanakan kegiatan ini.

\section{DAFTAR RUJUKAN}

Adekoya, A. E. (2009). Food insecurity and coping strategies among rural households in Oyo State, Nigeria. Journal of Food, Agriculture and Environment, 7(3-4), 187-191.

Charina, A., Kusumo, R. A. B., Sadeli, A. H., \& Deliana, Y. (2018). Faktor-faktor yang Mempengaruhi Petani dalam Menerapkan Standar Operasional Prosedur (SOP) Sistem Pertanian Organik di Kabupaten Bandung Barat. Jurnal Penyuluhan, 14(1), 6878. https://doi.org/10.25015/penyuluhan.v14i1.16752

Hasan, N., Alphinia, A., Megawati, Rahmatun, R., Alchamda, I., Zaki, A., ... Sujana, W. S. (2020). Pemanfaatan lahan desa sebagai tempat penanaman bunga untuk memperindah desa. Jurnal Pembelajaran Pemberdayaan Masyarakat (JP2M), 1(3), 222-226. 
https://doi.org/10.33474/jp2m.v1i3.6580

Ilham, N., \& Sinaga, B. M. (2007). Penggunaan Pangsa Pengeluaran Pangan Sebagai Indikator Komposit Ketahanan Pangan. SOCA (Socio-Economic of Agriculturre and Agribusiness), 7(3), 1-22. Retrieved from https://ojs.unud.ac.id/index.php/soca/article/view/4217

Istiqomah, \& Serdani, A. D. (2018). Pertumbuhan dan Hasil Tanaman Sawi (Brassica juncea L. Var. Tosakan) Pada Pemupukan Organik, Anorganik dan Kombinasinya. AGRORADIX: Jurnal Ilmu Pertanian, 1(2), 1-8. Retrieved from http://ejurnal.unisda.ac.id/index.php/agro/article/view/919

Karamina, H., Supriyadi, S., Firman Yasin, D. D., Yusi Kamhar, M., \& Kusuma Astuti, F. (2020). Pemanfaatan dan Penanaman Tanaman Obat Keluarga (TOGA) Menuju Keluarga Sehat Pada Ibu Pemberdayaan Kesejahteraan Keluarga (PKK). Jurnal Inovasi Hasil $\begin{array}{lll}\text { Pengabdian } \quad \text { Masyarakat } & \text { (JIPEMAS), }\end{array}$ https://doi.org/10.33474/jipemas.v3i2.6416

Lukmanto, C. M. E., \& Nirwansjah, R. (2015). Konsep Agrikultur Sebagai Penyelesaian dari Isu Pertanian. Jurnal Saint Dan Seni ITS, 4(2), 82-87. https://doi.org/10.12962/j23373520.v4i2.12632

Mayrowani, H. (2012). Pengembangan Pertanian Organik di Indonesia. Forum Penelitian Agro Ekonomi, 30(2), 91. https://doi.org/10.21082/fae.v30n2.2012.91-108

Mulyo, J. H., Sugiyarto, S., \& Widada, A. W. (2016). Ketahanan Dan Kemandirian Pangan Rumah Tangga Tani Daerah Marginal Di Kabupaten Bojonegoro. Agro Ekonomi, 26(2), 121-128. https://doi.org/10.22146/agroekonomi.17265

Rachman, H. P., Ariani, M., \& Purwantini, T. B. (2008). Distribusi Provinsi di Indonesia Menurut Derajat Ketahanan Pangan Rumah Tangga. Bogor: Pusat Analisis Sosial Ekonomi dan Kebijakan Pertanian.

Rahayu, T. B., Simanjuntak, B. H., \& Suprihati. (2014). PEMBERIAN KOTORAN KAMBING TERHADAP PERTUMBUHAN DAN HASIL WORTEL (Daucus carota) DAN BAWANG DAUN (Allium fistulosum L.) DENGAN BUDIDAYA TUMPANGSARI. Agric, 26(1), 5260. https://doi.org/10.24246/agric.2014.v26.i1.p52-60

Sholihah, A., \& Nurhidayati. (2018). IbM KELOMPOK TANI HORTIKULTURA DALAM RANGKA PERBAIKAN MANAJEMEN PRODUKSI KOMPOS. Jurnal Inovasi Hasil $\begin{array}{lll}\text { Pengabdian Masyarakat } & \text { (JIPEMAS), } & \text { 94-104. }\end{array}$ https://doi.org/10.33474/jipemas.v1i2.1513 